\title{
Original article DOI: $10.19027 /$ jai.19.1.50-60 \\ Growth performance and immune response of catfish Clarias sp. given probiotics Bacillus megaterium PTB 1.4 and Pediococcus pentosaceus E2211
}

\section{Kinerja pertumbuhan dan respons imun ikan lele Clarias sp. yang diberi probiotik Bacillus megaterium PTB 1.4 dan Pediococcus pentosaceus E2211}

\author{
Muhammad Subhan Hamka ${ }^{1}$, Anja Meryandini², Widanarni ${ }^{*}$

\begin{abstract}
'Department of Aquaculture, Faculty of Fisheries and Marine Sciences, IPB University, Bogor, Indonesia 16680 ${ }^{2}$ Department of Biology, Faculty of Mathematics and Natural Sciences, IPB University, Bogor, Indonesia 16680
\end{abstract} \\ * Corresponding author: widanarni@yahoo.com
}

(Received June 2, 2019; Accepted August 27, 2019)

\begin{abstract}
Motile aeromonad septicaemia (MAS) in catfish can be done by improving the immune responses through probiotic administration. Co-administering probiotics producing digestive enzymes are expected to have an impact on fish growth. This study was aimed to evaluate the effectivity of probiotics B. megaterium PTB 1.4 and P. pentosaceus E2211 to improve the growth performance and immune response of catfish infected by Aeromonas hydrophila. Catfish with the initial body weight of $7.36 \pm 0.21 \mathrm{~g}$ were reared in a pond. This study was conducted with five treatments, i. e. K- (without probiotic addition and A. hydrophila injection), $\mathrm{K}+$ (no probiotic addition with $A$. hydrophila injection), Bm (B. megaterium PTB 1.4 addition and $A$. hydrophila injection), Pp (P. pentosaceus E2211 addition and A. hydrophila injection), and $\mathrm{Bm}+\mathrm{Pp}(B$. megaterium PTB 1.4 addition and $P$. pentosaceus E2211 and A. hydrophila injection). The study results showed that $\mathrm{Bm}, \mathrm{Pp}$, and $\mathrm{Bm}+\mathrm{Pp}$ treatments were able to improve the growth performance of catfish including digestive enzyme activity, daily growth rate, feed conversion ratio, and final biomass with the best results was $\mathrm{Bm}+\mathrm{Pp}$ treatment. The immune response of catfish before and after the challenge test showed better survival rate, higher total leukocytes, phagocytic activity, respiratory burst, and lysozyme activity on $\mathrm{Bm}, \mathrm{Pp}$, and $\mathrm{Bm}+\mathrm{Pp}$ treatment $(\mathrm{P}<0.05)$ than the control treatment. In conclusion, the combination of probiotics B. megaterium PTB 1.4 and P. pentosaceus E2211 in feed synergistically improved the growth performance and immune response on catfish against $A$. hydrophila infection.
\end{abstract}

Keywords: Aeromonas hydrophila, catfish, growth performance, immune response, probiotics

\begin{abstract}
ABSTRAK
Motile aeromonad septicaemia (MAS) pada ikan lele dapat dikendalikan melalui respons imun inang dengan pemberian probiotik. Pemberian bersama probiotik penghasil enzim pencernaan diharapkan dapat berdampak pada pertumbuhan ikan. Penelitian ini bertujuan mengevaluasi efektivitas pemberian probiotik $B$. megaterium PTB 1.4 dan P. pentosaceus E2211 terhadap kinerja pertumbuhan dan respons imun ikan lele terhadap infeksi $A$. hydrophila. Ikan lele dengan bobot $7.36 \pm 0.21 \mathrm{~g}$ dipelihara pada kolam beton yang diberi waring. Penelitian ini menggunakan rancangan acak lengkap dengan lima perlakuan, yaitu: K- (tanpa probiotik dan tanpa diinjeksi $A$. hydrophila), $\mathrm{K}+$ (tanpa probiotik dan diinjeksi A. hydrophila), Bm (diberi B. megaterium PTB 1.4 dan diinjeksi $A$. hydrophila), $\mathrm{Pp}$ (diberi P. pentosaceus E2211 dan diinjeksi A. hydrophila), dan $\mathrm{Bm}+\mathrm{Pp}$ (diberi B. megaterium $\mathrm{PTB}$ 1.4 dan P. pentosaceus E2211 dan diinjeksi A. hydrophila). Hasil penelitian menunjukkan perlakuan Bm, Pp, dan $\mathrm{Bm}+\mathrm{Pp}$ mampu meningkatkan pertumbuhan ikan lele. Aktivitas enzim pencernaan, laju pertumbuhan harian, rasio konversi pakan, dan biomassa panen dengan hasil terbaik yaitu perlakuan $\mathrm{Bm}+\mathrm{Pp}$. Respons imun ikan lele dengan kombinasi probiotik B. megaterium PTB 1.4 dan P. pentosaceus E2211 mampu meningkatkan sintasan, total leukosit, aktivitas fagositosis, respiratory burst, dan aktivitas lisozim, baik pada sebelum dan setelah uji tantang. Pemberian kombinasi probiotik B. megaterium PTB 1.4 dan P. pentosaceus E2211 pada pakan mampu bekerja sinergis dalam meningkatkan kinerja pertumbuhan dan respons imun ikan lele terhadap infeksi A. hydrophila.
\end{abstract}




\section{INTRODUCTION}

Catfish Clarias sp. is one of the main aquaculture commodities in Indonesia, especially in Java Island. According to KKP (2017), the catfish production in 2014 reached 485,687 ton and improved until 541,024 ton in 2016. This condition was fulfilled through an intensive culture system, which potentially brought bad impacts, such as water quality reduction and disease attack potential induction. One of the diseases which generally attacks in catfish culture is motile aeromonad septicaemia (MAS) or known as hemorrhagic caused by Aeromonas hydrophila infection with 80-100\% mortality rate (Asniatih et al., 2013).

A method to overcome this disease generally uses antibiotics, although it can cause some risks, i.e pathogenic bacterial resistance, enviromental water pollution, and antibiotic residue on the aquaculture products, therefore their use has been limited (Michael el al., 2014). One alternative solution to resolve these condition is through the probiotic application. Probiotics are defined as microorganisms with the ability of modifying the bacterial composition in the digestive tract of aquatic animals, water, and sediments. Probiotics have been utilized as a feed supplement that can improve the immune response, feed nutrient value, and become biocontrol agent (Flores, 2011).

Somes studies reported that the probiotic bacterial roles to induce the host immune response against the pathogenic bacterial infection, such as on striped catfish against $A$. hydrophila (Tamamdusturi et al., 2016) and common carp against A. hydrophila (Djauhari et al., 2016). Besides disease, the intensive aquaculture is faced on the minimum commercial feed digestibility rate. The probiotic bacteria can produce some enzymes to improve the feed digestibility, such as amylase, protease, lipase, and cellulose by hydrolyzing the feed nutrients (breaking down carbohydrates, proteins, and lipids into simpler molecules), therefore facilitating the digestion process and nutrient absorption on fish digestive tract (Putra \& Widanarni, 2015). Some studies reported that the bacterial probiotic roles are in improving the digestive enzymes and growth, namely on nile tilapia (Putra \& Widanarni, 2015) and vannamei shrimp (Widanarni et $a l$. , 2015). The bacterial probiotics used in this study was Bacillus megaterium PTB 1.4 isolated from catfish digestive tract (Hamtini et $a l ., 2015)$, which had been tested effectively to improve catfish growth performance (Afrilasari et al., 2017). Pediococcus pentosaceus E2211 bacteria isolated from corn meal spontaneous fermentation (Rosyidah et al., 2013) and had been tested to improce the catfish resistance against $A$. hydrophila (Turnip et al., 2018). Therefore, the co-application of B. megaterium PTB 1.4 and P. pentosaceus E2211 bacteria is expected to synergically improve the growth performance and immune response of catfish against $A$. hydrophila infection. This study was aimed to evaluate the administration effectivity of $B$. megaterium PTB 1.4 and $P$. pentosaceus E2211 probiotics on the growth performance and immune response of catfish against $A$. hydrophila infection.

\section{MATERIALS DAN METHODS}

\section{Period and location}

This study was conducted in October, 2018 until March, 2019 in the Laboratory of Fish Health, Department of Aquaculture, Faculty of Fisheries and Marine Sciences IPB University, Laboratory of Microbiology, Research Centre for Bioresources and Biotechnology (RCBB) IPB University, and research ponds of Nur Ar Rohman Islamic Boarding School, Tegal Waru Village, Bogor Regency.

\section{Probiotics preparation}

Bacterial probiotics used in this study were B. megaterium PTB 1.4 isolated by Hamtini et al. (2014) from the catfish digestive tract and $P$. pentosaceus E2211 isolated by Rosyidah et al. (2013) from corn meal spontaneous fermentation result. These two probiotic bacteria were given a rifampicin antibiotic resistance marker $(B$. megaterium $\mathrm{PTB}$ 1.4 $\mathrm{Rf}^{\mathrm{R}}$ and P. pentosaceus $\mathrm{E} 2211$ $\mathrm{Rf}^{\mathrm{R}}$ ). B. megaterium PTB 1.4 $\mathrm{Rf}^{\mathrm{R}}$ were cultured on tryptic soy broth (TSB) media and incubated on the waterbath shaker $\left(140 \mathrm{rpm}, 29^{\circ} \mathrm{C}\right)$ for 12 hours. P. pentosaceus E2211 $\mathrm{Rf}^{\mathrm{R}}$ were cultured on deMan, Rogosa, and Sharpe broth (MRSB) media and incubated on an anaerobic $\left(37^{\circ} \mathrm{C}\right)$ for 18 hours. These two freshly harvested isolates were then centrifuged ( $9000 \mathrm{rpm}$ ) for 5 minutes to obtain probiotic pellets. The probiotic pellets were homogenized in $0.1 \mathrm{~mL}$ sterile $\mathrm{NaCl} 0.85 \%$.

\section{Study design}

This study contained five treatments and three replications, namely: (K-) commercial feed given without probiotic addition and A. hydrophila injection; $(\mathrm{K}+)$ commercial feed given without 
probiotic addition, but with $A$. hydrophila injection; $(\mathrm{Bm})$ commercial feed given with $1 \%$ B. megaterium PTB 1.4 probiotics addition and A. hydrophila injection; (Pp) commercial feed given with $1 \%$ P. pentosaceus E2211 probiotics addition and $A$. hydrophila injection; $(\mathrm{Bm}+\mathrm{Pp})$ commercial feed given with $1 \%$ B. megaterium PTB $1.4+P$. pentosaceus E2211 probiotics addition and $A$. hydrophila injection.

\section{Test feed preparation}

The feed used was a commercial feed with $39-41 \%$ protein content. Feed was added with B. megaterium $\mathrm{PTB} 1.4 \mathrm{Rf}^{\mathrm{R}}$ probiotics, $P$. pentosaceus E2211 $\mathrm{Rf}^{\mathrm{R}}$ probiotics, and both probiotic combination, which had been prepared before with each probiotic age of 12 and 18 hours respectively. Feed was then tested the probiotic bacterial vialibility by calculation using a spread method on tryptic soy agar (TSA) media $+50 \mu \mathrm{g} /$ $\mathrm{mL}$ Rifampicin (for B. megaterium PTB 1.4 $\mathrm{Rf}^{\mathrm{R}}$ ) and deMan, Rogosa and Sharpe Agar (MRSA) + $50 \mu \mathrm{g} / \mathrm{mL}$ Rifampicin (for P. pentosaceus E2211 $\mathrm{Rf}^{\mathrm{R}}$ ). The viability of probiotic bacteria in feed was $10^{6} \mathrm{CFU} / \mathrm{g}$ feed.

\section{Pond and rearing media preparation}

The pond used in this study was a concrete tank sized $7500 \times 400 \times 60 \mathrm{~cm}^{3}$ given a net sized $100 \times 30 \times 80 \mathrm{~cm}^{3}$ with 15 units. Pond was cleaned first and dried. Water was filled until $30 \mathrm{~cm}$ height, then given $227.78 \mathrm{mg} / \mathrm{L}$ limestone and filled with water until $50 \mathrm{~cm}$ height. Then, added with 55.56 $\mathrm{mg} / \mathrm{L}$ mollase, $555.56 \mathrm{mg} / \mathrm{L}$ manure, $1.1 \mathrm{mg} / \mathrm{L}$ yeast, and stood for a week until the water turned into green.

\section{Test animal preparation and rearing}

Test fish used were catfish originated from the catfish culturist in Bogor, West Java. Fish with the initial weight of $7.36 \pm 0.21 \mathrm{~g}$ were acclimatized for one week before udes as the test animal and given a standard commercial feed during the acclimatization process. After the acclimatization process had performed, catfish were reared with $30 \mathrm{fish} /$ net density for 30 days and fed three times a day at $04.00,18.00$, and $23.00(\mathrm{GMT}+7)$ at satiation.

\section{Challenge test}

Challenge test was performed on the catfish, a day after reared for 30 days with feed test given. Fish were injected intramuscularly with pathogenic bacterial suspension of $A$. hydrophila with $0.1 \mathrm{~mL} 10^{6} \mathrm{CFU} / \mathrm{mL}$ per individual using a sterile syringe. The fish treatment on the negative control (K-) were moved into another pond with the sam water condition and injected with phosphate buffered saline (PBS). Catfish was then reared again for 10 days given a standard commercial feed and performed an observation on each day.

\section{Parameters}

Growth performance

After 30 days of rearing with the test feed, the fish daily growth rate (DGR) and feed conversion ratio (FCR) were calculated based on Akrami et al. (2013).

\section{Total probiotic bacteria on the digestive tract}

The measurement of total probiotic population was performed after 30 days of rearing using Van Doan et al. (2018) method. Catfish digestive tract was taken and measured as much as $0.1 \mathrm{~g}$, then crushed and serially diluted using a sterile PBS solution. The diluted sample was spreaded onto TSA, TSA $+50 \mu \mathrm{g} / \mathrm{mL}$ Rifampicin, and MRSA $+50 \mu \mathrm{g} / \mathrm{mL}$ Rifampicin media to determine the total digestive bacteria, B. megaterium PTB 1.4 $\mathrm{Rf}^{\mathrm{R}}$, and $P$. pentosaceus E2211 $\mathrm{Rf}^{\mathrm{R}}$ respectively in the digestive tract of catfish on each treatment. The total bacterial colony was calculated and presented in colony forming unit (CFU/g).

Protease and amylase enzyme activity of digestive tract

Protease and amylase enzyme activity in the digestive tract was analyzed after 30 days of rearing. Each fish treatment was taken and measured its digestive tract as much as $1 \mathrm{~g}$, then crushed added with $5 \mathrm{~mL}$ phosphate buffer 0.05 M, pH 7.5 and homogenized. Samples were then centrifuged with $6000 \mathrm{rpm}$ at $4^{\circ} \mathrm{C}$ for 30 minutes. The enzyme crude extracts obtained were tested their activities. Protease enzyme activity was measured based on Walter (1984) method with modification. Amylase enzyme activity was measured based on Bernfeld (1955) method.

\section{Immune response}

Total leucocyte measurement followed the procedure of Chen et al. (2019). The phagocytic activity was observed through a blood slide of Anderson and Siwicki (1993). The respiratory burst and lysozyme activity were observed following the procedure of Hanif et al. (2004). 
Total A. hydrophila in the target organ

Total A. hydrophila measurement was performed using Van Doan et al. (2018) method. Liver and kidney target organ with 0.1 $\mathrm{g}$ respectively were crushed and serially diluted using a sterile PBS. The dilution result on each tube was spreaded on Rimler-Shotts (RS) media as much as $0.05 \mathrm{~mL}$ to determine total A. hydrophila bacteria in the kidney and liver of catfish. The observation was performed on day 30th, 35th, and 40th.

\section{Data analysis}

The data obtained were tabulated with WPS Office S preadsheet 2 019. D ata w ere a nalyzed using a one-way ANOVA (analysis of variance) with SPSS version 16.0 with $95 \%$ degree of confidence, when there was a significant difference among treatments, data were tested using a Duncan test.

\section{RESULT AND DISCUSSION}

\section{Result}

\section{Growth performance}

Survival rate $(\mathrm{SR})$, final biomass $\left(\mathrm{B}_{\mathrm{t}}\right)$, daily growth rate (DGR), and feed conversion ratio (FCR) of catfish after reared for 30 days are presented on Table 1. The survival rate after 30 days of rearing did not show any differences on all treatments. The initial biomass $\left(\mathrm{B}_{0}\right)$ of fish was the same on all treatments, while the final biomass $\left(B_{t}\right)$ of fish on $\mathrm{Bm}+\mathrm{Pp}$ treatment $(1118.54 \pm 21.11$ $\left.\mathrm{g} / \mathrm{m}^{2}\right)$ was higher $(\mathrm{P}<0.05)$ than other treatments. The daily growth rate on $\mathrm{Bm}+\mathrm{Pp}$ treatment (5.46 $\pm 0.17 \%$ /day) was also higher $(\mathrm{P}<0.05)$ than other treatments. The feed conversion ration on $\mathrm{Bm}$ $(0.54 \pm 0.01), \mathrm{Bm}+\mathrm{Pp}(0.60 \pm 0.01)$, and $\mathrm{Pp}(0.63$ $\pm 0.05)$ treatment showed lower values $(\mathrm{P}<0.05)$ than control. Probiotics addition in feed for 30 days improved DGR, which caused a reduced FCR compared to control.

\section{Total probiotic bacteria in the digestive tract}

After 30 days of rearing, total bacteria and probiotic bacteria in the digestive tract are presented on Table $1 . \mathrm{Bm}(8.41 \pm 0.04 \mathrm{log}$ $\mathrm{CFU} / \mathrm{g}), \mathrm{Pp}(8.67 \pm 0.01 \log \mathrm{CFU} / \mathrm{g})$, and $\mathrm{Bm}+\mathrm{Pp}$ $(8.67 \pm 0.01 \log \mathrm{CFU} / \mathrm{g})$ treatment showed higher total digestive tract bacteria $(\mathrm{TB})(\mathrm{P}<0.05)$ than control treatment $(7.79 \pm 0.00 \log \mathrm{CFU} / \mathrm{g})$. Probiotics B. megaterium PTB 1.4 Rf ${ }^{\mathrm{R}}$ were only found in treatmet $\mathrm{Bm}$ and $\mathrm{Bm}+\mathrm{Pp}$ with the total B. megaterium PTB 1.4 $\mathrm{Rf}^{\mathrm{R}}(\mathrm{TBBm})$ was 6.60 $\pm 0.01 \log \mathrm{CFU} / \mathrm{g}$ and $6.61 \pm 0.00 \mathrm{log} \mathrm{CFU} / \mathrm{g}$ respectively, while on treatment $\mathrm{Pp}$ and control were not found probiotics B. megaterium PTB 1.4 $\mathrm{Rf}^{\mathrm{R}}$. Moreover, probiotics $P$. pentosaceus $\mathrm{E} 2211$ $\mathrm{Rf}^{\mathrm{R}}$ (TBPp) were only found on Pp (6.49 \pm 0.01 $\log \mathrm{CFU} / \mathrm{g})$ and $\mathrm{Bm}+\mathrm{Pp}(6.50 \pm 0.01 \log \mathrm{CFU} / \mathrm{g})$ treatment, while on $\mathrm{Bm}$ and control treatment was not found probiotics $P$. pentosaceus E2211 $\mathrm{Rf}^{\mathrm{R}}$

Protease and amylase enzyme activity in the digestive tract

Probiotics B. megaterium PTB 1.4 and $P$. pediococcus E2211 given in feed for 30 days showed higher protease enzyme activity on $\mathrm{Bm}$ and $\mathrm{Bm}+\mathrm{Pp}$ treatment $(\mathrm{P}<0.05$, Figure 1a) than

Table 1. Survival rate (SR), initial biomass $\left(\mathrm{B}_{0}\right)$, final biomass $\left(\mathrm{B}_{\mathrm{t}}\right)$, daily growth rate (DGR), feed intake (FI), feed conversion ratio (FCR), total digestive tract bacteria (TB), total B. megaterium PTB1.4 in digestive tract (TBBm) and total P. pentosaceus E2211 in digestive tract (TBPp) in catfish after 30 days of rearing.

\begin{tabular}{cccccc}
\hline \multirow{2}{*}{ Parameter } & \multicolumn{5}{c}{ Treatment } \\
\cline { 2 - 6 } & K- & K+ & Bm & Pp & Bm+Pp \\
\hline SR $(\%)$ & $98.89 \pm 1.92^{\mathrm{a}}$ & $97.78 \pm 3.85^{\mathrm{a}}$ & $94.44 \pm 1.92^{\mathrm{a}}$ & $95.56 \pm 3.85^{\mathrm{a}}$ & $97.78 \pm 1.92^{\mathrm{a}}$ \\
B $_{0}\left(\mathrm{~g} / \mathrm{m}^{2}\right)$ & $220.18 \pm 8.36^{\mathrm{a}}$ & $220.89 \pm 7.80^{\mathrm{a}}$ & $222.20 \pm 6.25^{\mathrm{a}}$ & $221.40 \pm 1.20^{\mathrm{a}}$ & $222.51 \pm 10.16^{\mathrm{a}}$ \\
B $_{\mathrm{t}}\left(\mathrm{g} / \mathrm{m}^{2}\right)$ & $945.38 \pm 38.86^{\mathrm{a}}$ & $915.81 \pm 7.21^{\mathrm{a}}$ & $938.80 \pm 16.52^{\mathrm{a}}$ & $928.27 \pm 90.11^{\mathrm{a}}$ & $1118.54 \pm 21.11^{\mathrm{b}}$ \\
DGR (\%/day) & $4.89 \pm 0.13^{\mathrm{a}}$ & $4.82 \pm 0.26^{\mathrm{a}}$ & $4.99 \pm 0.11^{\mathrm{a}}$ & $4.92 \pm 0.20^{\mathrm{a}}$ & $5.46 \pm 0.17^{\mathrm{b}}$ \\
FI (g) & $538.67 \pm 0.58^{\mathrm{c}}$ & $584.70 \pm 0.44^{\mathrm{e}}$ & $395.32 \pm 0.21^{\mathrm{a}}$ & $466.77 \pm 0.59^{\mathrm{b}}$ & $549.07 \pm 0.51^{\mathrm{d}}$ \\
FCR & $0.74 \pm 0.03^{\mathrm{c}}$ & $0.82 \pm 0.06^{\mathrm{d}}$ & $0.54 \pm 0.01^{\mathrm{a}}$ & $0.63 \pm 0.05^{\mathrm{b}}$ & $0.60 \pm 0.01^{\mathrm{ab}}$ \\
TB $(\log$ CFU/g) & $7.79 \pm 0.00^{\mathrm{a}}$ & $7.84 \pm 0.01^{\mathrm{b}}$ & $8.41 \pm 0.04^{\mathrm{c}}$ & $8.67 \pm 0.01^{\mathrm{d}}$ & $8.67 \pm 0.01^{\mathrm{d}}$ \\
TBBm $(\log$ CFU/g) & $0.00^{\mathrm{a}}$ & $0.00^{\mathrm{a}}$ & $6.60 \pm 0.01^{\mathrm{b}}$ & $0.00^{\mathrm{a}}$ & $6.61 \pm 0.00^{\mathrm{b}}$ \\
TBPp $(\log$ CFU/g) & $0.00^{\mathrm{a}}$ & $0.00^{\mathrm{a}}$ & $0.00^{\mathrm{a}}$ & $6.49 \pm 0.01^{\mathrm{b}}$ & $6.50 \pm 0.01^{\mathrm{c}}$ \\
\hline
\end{tabular}

Note: Different superscript letters on the same line show a significant different treatment influence (Duncan, $\mathrm{P}<0.05)$. Values are presented as average and standard deviation, $\mathrm{K}-$ : negative control, $\mathrm{K}+$ : positive control, Bm: $B$. megaterium PTB 1.4, Pp: P. pentosaceus E2211, Bm+Pp: B. megaterium PTB $1.4+$ P. pentosaceus E2211 


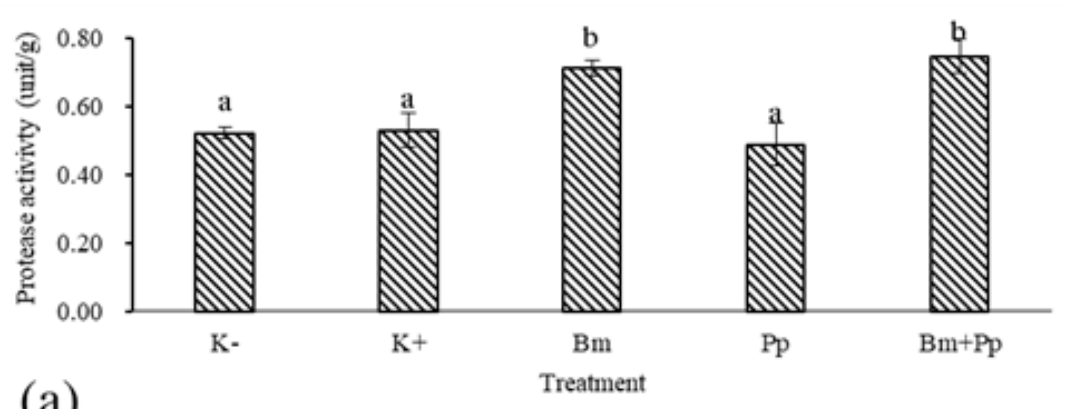

(a)

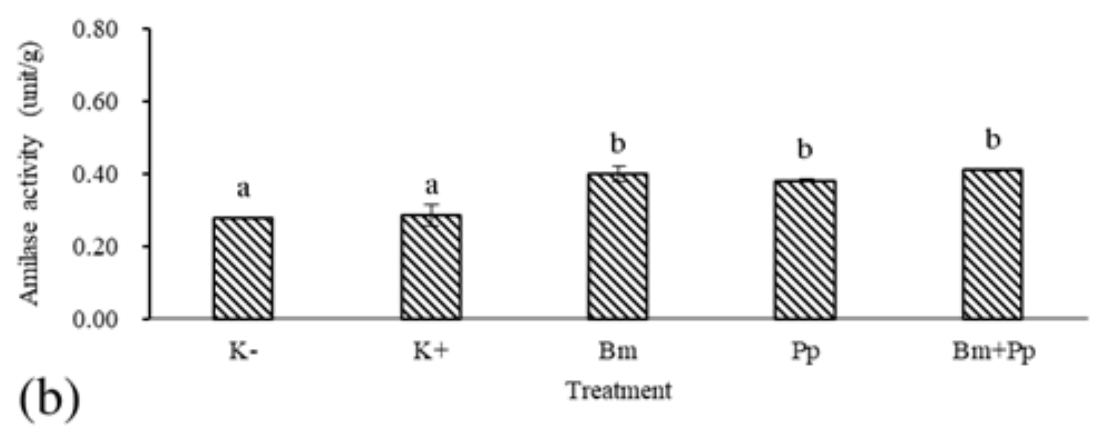

Figure 1 (a-b). Protease and amylase enzyme activity in the digestive tract of catfish after 30 days of rearing. Different letters above the bars show a significant $(\mathrm{P}<0.05)$. Negative control $(\mathrm{K}-)$, positive control $(\mathrm{K}+), B$. megaterium PTB 1.4 addition (Bm), P. pentosaceus E2211 addition (Pp), B. megaterium PTB $1.4+$ P. pentosaceus E2211 addition (Bm+Pp).

Table 2. Survival rate (SR) on post-challenge test, total leucocytes (TL), phagocytic activity (PA), respiratory burst activity (RB), and lysozyme activity (LA) of catfish at $0,30,35$, and 40 days of rearing.

\begin{tabular}{|c|c|c|c|c|c|c|}
\hline \multirow{2}{*}{ Parameter } & \multirow{2}{*}{ Day } & \multicolumn{5}{|c|}{ Treatment } \\
\hline & & $\mathrm{K}-$ & $\mathrm{K}+$ & $\mathrm{Bm}$ & $\mathrm{Pp}$ & $\mathrm{Bm}+\mathrm{Pp}$ \\
\hline \multirow[t]{2}{*}{$\begin{array}{l}\text { Post-challenge test } \\
\text { SR }(\%)\end{array}$} & 40 & $100 \pm 0.00^{c}$ & $43.17 \pm 6.67^{\mathrm{a}}$ & $84.69 \pm 5.52^{b}$ & $88.41 \pm 1.51^{\mathrm{b}}$ & $87.51 \pm 1.87^{\mathrm{b}}$ \\
\hline & 0 & $1.45 \pm 0.35^{\mathrm{a}}$ & $1.45 \pm 0.35^{\mathrm{a}}$ & $1.45 \pm 0.35^{\mathrm{a}}$ & $1.45 \pm 0.35^{\mathrm{a}}$ & $1.45 \pm 0.35^{\mathrm{a}}$ \\
\hline \multirow{4}{*}{$\begin{array}{l}\text { Total leucocytes } \\
\left(10^{4} \text { cells/mm } / \mathrm{mm}^{3}\right)\end{array}$} & 30 & $2.08 \pm 0.03^{\mathrm{ab}}$ & $2.30 \pm 0.05^{\mathrm{cd}}$ & $2.22 \pm 0.02^{\mathrm{bc}}$ & $2.44 \pm 0.01^{\mathrm{d}}$ & $2.01 \pm 0.20^{\mathrm{a}}$ \\
\hline & 35 & $3.21 \pm 0.07^{\mathrm{a}}$ & $3.41 \pm 0.10^{\mathrm{a}}$ & $3.43 \pm 0.31^{\mathrm{a}}$ & $4.49 \pm 0.09^{b}$ & $4.57 \pm 0.35^{\mathrm{b}}$ \\
\hline & 40 & $0.99 \pm 0.03^{b}$ & $1.60 \pm 0.10^{c}$ & $0.99 \pm 0.04^{\mathrm{b}}$ & $0.78 \pm 0.07^{\mathrm{a}}$ & $1.03 \pm 0.02^{\mathrm{b}}$ \\
\hline & 0 & $10.71 \pm 0.71^{\mathrm{a}}$ & $10.71 \pm 0.71^{\mathrm{a}}$ & $10.71 \pm 0.71^{\mathrm{a}}$ & $10.71 \pm 0.71^{\mathrm{a}}$ & $10.71 \pm 0.71^{\mathrm{a}}$ \\
\hline \multirow[t]{4}{*}{ Phagocytic activity } & 30 & $11.06 \pm 0.94^{a}$ & $11.96 \pm 0.54^{\mathrm{a}}$ & $11.96 \pm 0.54^{\mathrm{a}}$ & $12.14 \pm 0.62^{\mathrm{ab}}$ & $13.39 \pm 0.89^{b}$ \\
\hline & 35 & $14.44 \pm 1.92^{\mathrm{a}}$ & $27.58 \pm 0.95^{\mathrm{b}}$ & $25.79 \pm 0.84^{\mathrm{b}}$ & $33.37 \pm 0.89^{\circ}$ & $33.97 \pm 0.55^{\circ}$ \\
\hline & 40 & $14.46 \pm 0.31^{\mathrm{a}}$ & $23.89 \pm 0.96^{\mathrm{b}}$ & $13.97 \pm 0.55^{\mathrm{a}}$ & $14.10 \pm 1.32^{\mathrm{a}}$ & $15.56 \pm 1.92^{\mathrm{a}}$ \\
\hline & 0 & $0.19 \pm 0.010^{\mathrm{a}}$ & $0.19 \pm 0.010^{\mathrm{a}}$ & $0.19 \pm 0.010^{\mathrm{a}}$ & $0.19 \pm 0.010^{\mathrm{a}}$ & $0.19 \pm 0.010^{\mathrm{a}}$ \\
\hline \multirow{4}{*}{$\begin{array}{l}\text { Respiratory burst } \\
\quad(\lambda=630 \mathrm{~nm})\end{array}$} & 30 & $0.22 \pm 0.004^{\mathrm{a}}$ & $0.31 \pm 0.002^{\mathrm{b}}$ & $0.29 \pm 0.006^{\mathrm{b}}$ & $0.37 \pm 0.027^{\circ}$ & $0.57 \pm 0.011^{\mathrm{d}}$ \\
\hline & 35 & $0.22 \pm 0.007^{\mathrm{a}}$ & $0.27 \pm 0.004^{\mathrm{b}}$ & $0.33 \pm 0.010^{c}$ & $0.35 \pm 0.009^{\mathrm{c}}$ & $0.67 \pm 0.017^{d}$ \\
\hline & 40 & $0.22 \pm 0.012^{\mathrm{a}}$ & $0.23 \pm 0.009^{\mathrm{a}}$ & $0.27 \pm 0.008^{\mathrm{b}}$ & $0.25 \pm 0.008^{b}$ & $0.31 \pm 0.018^{c}$ \\
\hline & 0 & $6.70 \pm 0.55^{\mathrm{a}}$ & $6.70 \pm 0.55^{\mathrm{a}}$ & $6.70 \pm 0.55^{\mathrm{a}}$ & $6.70 \pm 0.55^{\mathrm{a}}$ & $6.70 \pm 0.55^{a}$ \\
\hline \multirow{3}{*}{$\begin{array}{l}\text { Lysozyme activity } \\
\text { (unit/mL) }\end{array}$} & 30 & $7.89 \pm 0.56^{\mathrm{a}}$ & $11.11 \pm 0.00^{\mathrm{b}}$ & $7.67 \pm 1.00^{\mathrm{a}}$ & $20.67 \pm 0.66^{\circ}$ & $26.17 \pm 1.72^{\mathrm{d}}$ \\
\hline & 35 & $1.56 \pm 0.22^{\mathrm{a}}$ & $2.78 \pm 0.48^{\mathrm{ab}}$ & $3.33 \pm 1.11^{\mathrm{b}}$ & $3.33 \pm 1.11^{\mathrm{b}}$ & $5.56 \pm 1.11^{\mathrm{c}}$ \\
\hline & 40 & $6.70 \pm 0.55^{\mathrm{c}}$ & $4.19 \pm 0.17^{b}$ & $2.22 \pm 0.00^{\mathrm{a}}$ & $3.56 \pm 0.89^{\mathrm{b}}$ & $4.44 \pm 0.02^{b}$ \\
\hline
\end{tabular}

Note: Different superscript letters on the same line show a significant difference (Duncan, $\mathrm{P}<0.05$ ). Values are presented average and standard deviation. K-: negative control, $\mathrm{K}+$ : positive control, Bm: B. megaterium PTB 1.4, Pp: P. pentosaceus E2211, Bm+Pp: B. megaterium PTB $1.4+$ + P. pentosaceus E2211. 

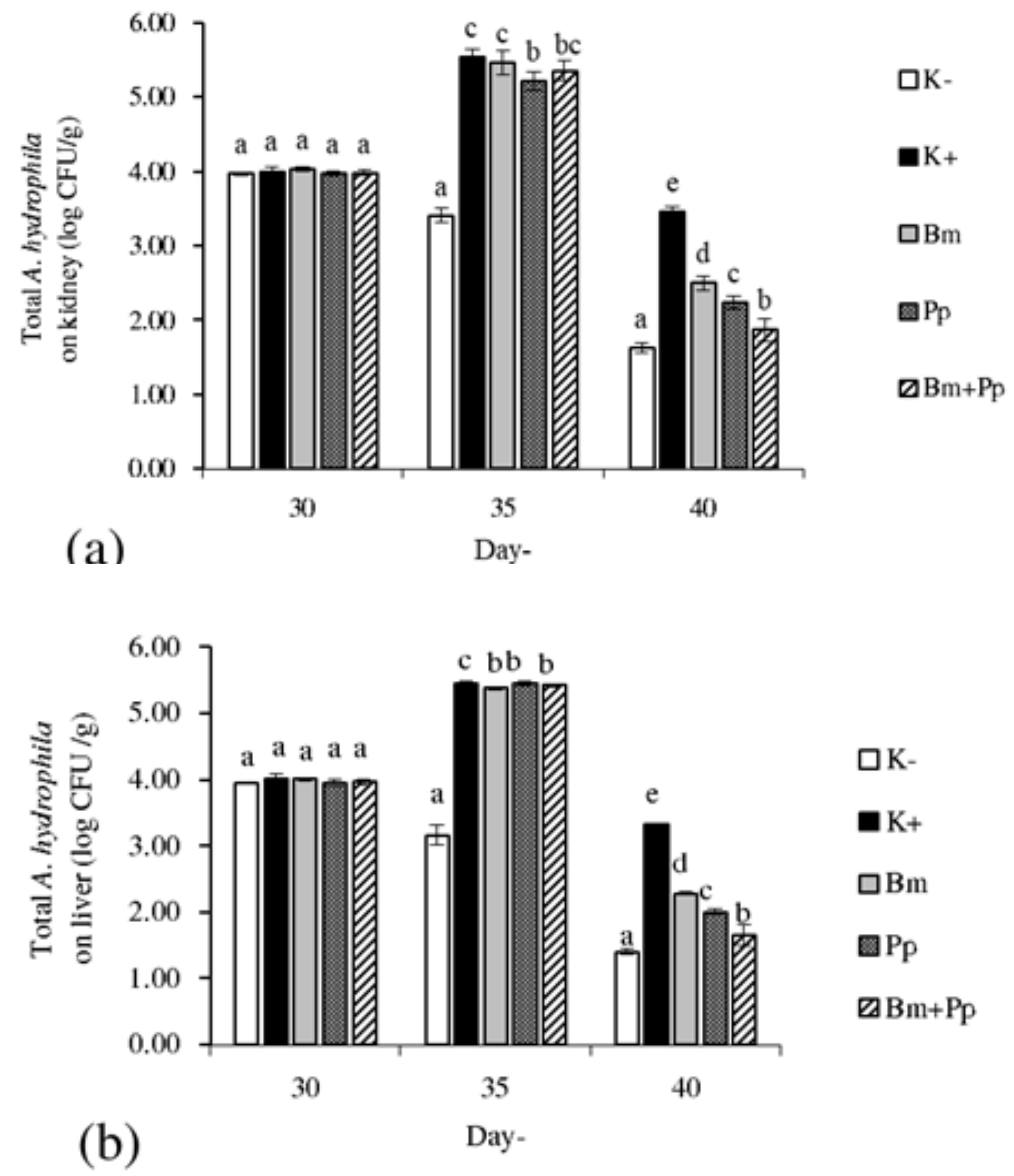

Figure 2 (a-b). Total A. hydrophila in the target organs: (a) liver (b) kidney of catfish on the post-challenge test. Different letters above bars show significant difference (Duncan, $\mathrm{P}<0.05)$. Negative control (K-), positive control $(\mathrm{K}+), 1 \%$ B. megaterium PTB 1.4 addition $(\mathrm{Bm}), 1 \%$ P. pentosaceus E2211 addition (Pp), 1\% B. megaterium PTB $1.4+1 \%$ P. pentosaceus E2211 addition $(\mathrm{Bm}+\mathrm{Pp})$.

other treatments (Pp and control). Meanwhile, amylase enzyme activity on $\mathrm{Bm}, \mathrm{Pp}$, and $\mathrm{Bm}+\mathrm{Pp}$ treatment was higher $(P<0.05$, Figure $1 b)$ than control treatment, however were insignificantly different among those probiotic treatments.

\section{Immune response}

Probiotics B. megaterium PTB 1.4 and $P$. pediococcus $\mathrm{E} 2211$ given in feed influenced the survival rate (SR) on the post-challenge test and blood profiles of catfish as presented on Table 2. Total leucocytes (TL), phagocytic activity (PA), respiratory burst activity (RB), and lysozyme activity (LA) had different values on each treatment, which represented a fish health status alteration. The SR value of $\mathrm{Bm}(84.69 \pm 5.52 \%)$, $\mathrm{Pp}(88.41 \pm 1.51 \%)$, and $\mathrm{Bm}+\mathrm{Pp}(87.51 \pm 1.87 \%)$ treatment was higher $(\mathrm{P}<0.05)$ than the positive control $(43.17 \pm 6.67 \%)$ on the 40th day (10 days of post-challenge test).

Total leucocyte of catfish on 0 day in all treatments showed the same value, i.e $1.45 \pm$
$0.35 \times 10^{4}$ cells $/ \mathrm{mm}^{3}$. After 30 days of rearing, total leucocytes was increased and Pp treatment $\left(4.49 \pm 0.09 \times 10^{4}\right.$ cells $\left./ \mathrm{mm}^{3}\right)$ was higher $(\mathrm{P}<0.05)$ than other treatments. Increased total leucocytes at the 35th day was higher than at the 30th day on all treatments, and the highest value was found on $\mathrm{Bm}+\mathrm{Pp}\left(4.57 \pm 0.35 \times 10^{4}\right.$ cells $\left./ \mathrm{mm}^{3}\right)$ followed with Pp treatment $\left(4.49 \pm 0.09 \times 10^{4}\right.$ cells $\left./ \mathrm{mm}^{3}\right)$ $(\mathrm{P}<0.05)$ compared to other treatments. Decreased total leucocytes happened at the 40th day in all treatments with the lowest value $(\mathrm{P}<0.05)$ was found on $\mathrm{Pp}$ treatment $\left(0.78 \pm 0.07 \times 10^{4}\right.$ cells/ $\left.\mathrm{mm}^{3}\right)$.

The phagocytic activity of catfish at 0 day showed the same value on each treatment, i.e $10.71 \pm 0.71 \%$. Phagocytic activity of catfish was increased at 30th day on all treatments, and $\mathrm{Bm}+\mathrm{Pp}$ treatment $(13.39 \pm 0.89 \%)$ showed higher FA value than other treatments. Phagocytic activity was continuously increased at the 35th day on all treatment, $\mathrm{Bm}+\mathrm{Pp}(33.97 \pm 0.55 \%)$ and $\mathrm{Pp}(33.37$ $\pm 0.89 \%)$ treatment was higher $(\mathrm{P}<0.05)$ than 
other treatments. Decreased phagocytic activity happened on all treatments at the 40th day, except on the positive control. The highest phagocytic activity value $(\mathrm{P}<0.05)$ was shown on the positive control with $23.89 \pm 0.96 \%$ compared to the other treatments.

Respiratory burst activity of catfish at 0 day showed no difference $(\mathrm{P}>0.05)$ with $0.19 \pm 0.01$. Increased respiratory burst happened at the 30th day, $\mathrm{Bm}+\mathrm{Pp}$ treatment $(0.57 \pm 0.011)$ showed higher value $(\mathrm{P}<0.05)$ than other treatments. Respiratory burst was continuously increased at the 35th day as $\mathrm{Bm}+\mathrm{Pp}$ treatment $(0.67 \pm$ 0.017) showed higher value $(\mathrm{P}<0.05)$ than other treatments. Respiratory burst activity was decreased at the 40th day as $\mathrm{Bm}+\mathrm{Pp}$ treatment $(0.31 \pm 0.018)$ had lower value than other treatments.

The lysozyme activity of catfish at 0 day showed no different value on each treatment with $6.70 \pm 0.55$ unit $/ \mathrm{mL}$. Lysozyme activity was increased on all treatments after 30 days of rearing, the highest value $(\mathrm{P}<0.05)$ was presented on $\mathrm{Bm}+\mathrm{Pp}$ treatment with $26.17 \pm 1.72$ unit $/ \mathrm{mL}$. Lysozyme activity was decreased at 35th day on all treatments as $\mathrm{Bm}+\mathrm{Pp}$ treatment showed the highest value $(\mathrm{P}<0.05)$ compared to other treatments with $5.56 \pm 1.11$. Increased lysozyme activity occured at the 40th day on $\mathrm{Pp}(3.56 \pm 0.89$ unit $/ \mathrm{mL}$ ) and positive control treatment, while $\mathrm{Bm}+\mathrm{Pp}(4.44 \pm 0.02$ unit $/ \mathrm{mL})$ and $\mathrm{Bm}(4.19 \pm$ $0.17 \mathrm{unit} / \mathrm{mL}$ ) treatment showed decreased values.

\section{Total A. hydrophila calculcation result on the tar-} get organ

Total A. hydrophila on the target organs of catfish on the post-challenge test is presented on Figure 2. Total A. hydrophila pathogenic bacteria in kidney and liver of catfish were the same on all treatments with approximate value of $3.97 \pm 0.02$ until $4.03 \pm 0.03 \mathrm{log} \mathrm{CFU} / \mathrm{g}$ at the 30th day. Total A. hydrophila pathogenic bacteria in liver and kidney of catfish at the 35th day was increased on all treatments, except the negative control (approximately $3.94 \pm 0.01$ until $4.00 \pm 0.08 \mathrm{log}$ CFU/g). Total A. hydrophila pathogenic bacteria at the 40th day was gradually decreased, $\mathrm{Bm}+\mathrm{Pp}$ treatment showed the lowest value in kidney $(1.87 \pm 0.15 \log \mathrm{CFU} / \mathrm{g})$ and liver $(1.65 \pm 016$ $\log \mathrm{CFU} / \mathrm{g})$, and significantly different $(\mathrm{P}<0.05)$ against other treatments.

\section{Discussion}

The results showed higher daily growth rate, feed conversion ratio, final biomass, digestive enzyme activities (protease and amylase) on $\mathrm{Bm}, \mathrm{Pp}$, and $\mathrm{Bm}+\mathrm{Pp}$ treatment than control. The existence of $B$. megaterium PTB 1.4 in the digestive tract of catfish (Table 1) was suspected to influence this condition. This followed the study results of Afrilasari et al. (2017) who used B. megaterium, Putra and Widanarni (2015) and Hauville et al. (2016) who used Bacillus sp., as well as Ferguson et al. (2010), Neissi et al. (2013), Adel et al. (2017), Valipour et al. (2018), and Gong et al. (2019) who reported the use of $P$. acidilactici and $P$. pentosaceus as digestive enzyme producing probiotics to improve the growth performance of catfish, green terror, grass carp, kutum, nile tilapia, common carp, and vannamei shrimp. Fish feed contains sufficiently high proteins as the main components in feed and energy source for fish. Feed that enters the fish digestive tract will be degraded by the digestive enzymes. B. megaterium PTB 1.4 has a proteolytic characteristic, which can secrete a protease enzyme to hydrolyze the peptide bonds in proteins to become oligopeptides and amino acids. Morevoer, B. megaterium PTB 1.4 also secretes amylase enzyme to breakdown carbohydrates into maltose and glucose. The best results were shown on $\mathrm{Bm}+\mathrm{Pp}$ treatment with the highest daily growth rate $(5.46 \pm 0.17 \% /$ hari $)$ and final biomass $\left(1118.54 \pm 21.11 \mathrm{~g} / \mathrm{m}^{2}\right)$ of catfish and significantly different $(\mathrm{P}<0.05)$ compared to other treatments. This was suspected due to the induced exogenous and endogenous enzyme activity in the digestive tract, therefore improving the daily growth rate and final biomass of catfish. The substrate availability in digestive tract can improve the exogenous and endogenous enzyme activities in digestive tract. Feed that enters into the fish digestive tract will be digested with the help of exogenous enzymes from the probiotic bacteria and endogenous enzymes produced by the fish (Afrilasari et al., 2017). The existence of endogenous and exogenous enzyme collaboration causes the feed is easily digested and absorbed by the fish body, therefore improving the growth performance of catfish after given probiotic treatments (Afrilasari et al., 2017).

The survival rate of catfish on the postchallenge test period indicated higher value $(\mathrm{P}<0.05)$ on $\mathrm{Bm}, \mathrm{Pp}$, and $\mathrm{Bm}+\mathrm{Pp}$ treatment than control. Normal physiological response and immune response against the disease attack can be detected by measuring the fish blood profiles. Based on the blood profile measurements (Table 
2), the total leucocytes (TL), phagocytic activity (PA), and respiratory burst activity (RB) improved after 30 days of rearing, and continuously improved at the 35th day of post-challenge test. This condition indicated that catfish fought against the pathogenic bacterial attack. The total leucocytes on $\mathrm{Bm}, \mathrm{Pp}$, and $\mathrm{Bm}+\mathrm{Pp}$ treatment were reduced at the 40th day, which indicated that catfish was gradually recovered.

The immune system on fish body contains two types, namely non-specific and specific immune. A non-specific immune system is divided into the first defense system or physical defense (such as scales and mucus) and second defense or humoral mechanism with plasmatic character, such as lysozyme, interferon, etc. (Uribe et al., 2011). The addition of B. megaterium PTB 1.4 and $P$. pentosaceus E2211 through feed could improve the value of TL, PA, and RB. The $\mathrm{Bm}+\mathrm{Pp}$ treatment showed the highest TL $(4.57 \pm$ $\left.0.35 \times 10^{4} \mathrm{sel} / \mathrm{mm}^{3}\right)$, PA $(33.97 \pm 0.55 \%)$, and RB $(0.67 \pm 0.017)$ at the 35 th day of post-challenge test, then reduced at the 40th day. Leucocytes play important roles on the non-specific immune system during the inflammation occurred and their number can become a fish health status indicator. TL and PA alteration happened when the fish suffered from an infection or stress condition. The increased TL during post-infection is related to the inflammatory response mediated by leucocytes to face the pathogenic bacterial infection. High TL after given probiotics for 30 days and 35 days after challenge test showed that the leucocytes were produced in high quantity to fight against the infection of $A$. hydrophila.

Leucocytes are blood cells that involves in the phagocytosis process. phagocytosis is the basic body defense and plays a role in limitting and breaking the foreign cells. The role of phagocytosis is mediated by monocytes, neutrophils, and macrophages as presented from the value of phagocytic activity (Awasthi et al., 2013). Phagocyte cells will kil the bacteria by producing reactive oxygens during the respiratory burst process (Uribe et al., 2011). Sugiani et al. (2013) stated that the higher respiratory burst activity, the greater production of free radicals used to fight the pathogens. The improved leucocytes, phagocytic activity, and respiratory burst indicated the health status of fish after given probiotics, namely $\mathrm{Bm}, \mathrm{Pp}$, and $\mathrm{Bm}+\mathrm{Pp}$ treatment at the 35th day compared to 30th day and 0 day was higher $(\mathrm{P}<0.05)$ than control. Total leucocytes, phagocytic activity, and respiratory burst activity at the 40th day on all probiotic treatments were decreased compared to the positive control. This condition showed that fish had undergone a recovery period towards the normal condition. This followed the study results of Bunnoy et al. (2019), who used Acinetobacter KU011TH on catfish and Silarudee et al. (2019) who used Lactobacillus plantarum CR1T5 on striped catfish could induce the respiratory burst activity compared to control.

Lysozyme is an important defense molecule in the form of proteins that involves in the nonspecific immune, including in fish and has a lytic activity against Gram positive and negative bacteria, besides activating the complement and phagocytosis system. Moreover, lysozyme can also hydrolyze the $\mathrm{N}$-acetilmuramate and $\mathrm{N}$-acetilglucosamine acid, which are the peptidoglycan layer components in the bacterial cell wall (Chen et al., 1996; Awasthi et al., 2013). Based on the measurement result of catfish lysozyme, all treatments showed increased value at the 30th day with the highest value was on $\mathrm{Bm}+\mathrm{Pp}$ treatment $(26.17 \pm 1.72$ unit $/ \mathrm{mL})$. This happened as B. megaterium and $P$. pentosaceus bacteria as Gram positive bacteria stimulated the lysozyme activity by producing bactericidal enzymes to figt against the disease agents. Nayak (2010) resported that probiotics either in single or combination could trigger the lysozyme level on Teleost fish. The lysozyme value was then gradually low at th 35 th day with $5.56 \pm 1.11$ unit $/ \mathrm{mL}$ and $4.44 \pm 0.02$ unit $/ \mathrm{mL}$ at the 40 th day. This condition was suspected due to the bacterial pathogen existence in the pond which had been attacked the catfish until the 30th day, as seen from high number of $A$. hydrophila in the target organs (either in kidney or liver), thefore most enzymes produced on the lysozyme activity were utilized in lyzing tha pathogenic bacteria, then finally the lysozyme activity was gradually reduced at th 35th and 40th day. Nasrullah et al. (2019) reported that the lysozyme activity in kidny and liver organ of catfish after infected with A. hydrophila was increased and reached an optimum point at the 12th hour, then gradually decreased until the normal condition.

The probiotic administration is known to be capable of improving the host resistance, as seen from continuously induced blood profile value and reduced total A. hydrophila pathogenic bacteria in the target organ. Catfish had undergone a recovery period at the 40th day with the best condition was obtained from $\mathrm{Bm}+\mathrm{Pp}$ treatment. This was 
shown on the low total A. hydrophila pathogenic bacteria $(\mathrm{P}<0.05)$ in kidney $(1.87 \pm 0.15 \log$ $\mathrm{CFU} / \mathrm{g})$ and $(1.65 \pm 0.16 \log \mathrm{CFU} / \mathrm{g})$ compared to other treatments. This condition was as same as the study results of Chen et al. (2018), who utilized probiotics Paenibacillys ehimensis on nile tilapia against the infection of $A$. hydrophila and Streptococcus iniae. One of the probiotic actions to inhibit the pathogen infection was by improving the host immune response thorugh the stimulation of body non-specific and cellular immunity (Fyzul et al., 2014). This condition happened as probiotics and components or their products are interacted with the gut associated lymphoid tissue (GALT) to induce the host immune response (Dimitriglou et al., 2011).

Based on the immune response parameter results above containing total leucocytes, phagocytic activity, respiratory burst activity, lysozyme activit, and total A. hydrophila pathogenica bacteria in the target organs of catfish before and after the challenge test, the probiotic treatments were generally better than the control treatment, especially on $\mathrm{Bm}+\mathrm{Pp}$ treatment, which was the combination of probiotics $B$. megaterium PTB 1.4 and P. pentosaceus E2211.

\section{CONCLUSION}

A combined probiotics of $B$. megaterium PTB 1.4 and $P$. pentosaceus E2211 given in feed can work synergistically to improve the growth performance and immune response of catfish against A. hydrophila infection.

\section{REFERENCES}

Adel M, Yeganeh S, Dawood MAO, Safari R, Radhakrishnan S. 2017. Effect of Pediococcus pentosaceus supplementation on growth performance, intestinal microflora and disease resistance of white shrimp, Litopenaeus vannamei. Aquaculture Nutrition 23: 14011409.

Afrilasari W, Widanarni, Meryandini A. 2017. Effect of probiotic Bacillus megaterium PTB 1.4 on the population of intestinal microflora, digestive enzyme activity and the growth of catfish Clarias sp.. Hayati Journal of Biosciences 23: 1-5.

Akrami R, Iri Y, Rostami HK, Mansour MR. 2013. Effect of dietary supplementation of fructooligosaccharide (FOS) on growth performance, survival, Lactobacillus bacterial population and hemato-immunological parameters of stellate sturgeon Acipenser stellatus juvenile. Fish \& Shellfish Immunology 35: 1235-1239.

Anderson DP, Siwicki AK. 1993. Basic hematology and serology for fish health programs. Di dalam: Shariff M, Arthur JR, Subasinghe JP, editor. Diseases in Asian Aquaculture II. 1993 Oktober 25-29: Phuket, Thailand. Manila (PH): Fish Health Section, Asian fisheries society. 185-202.

Asniatih M, Idris K, Saibu. 2013. Pathological change of African catfish Clarias gariepinus infected by Aeromonas hydrophila. Jurnal Mina Laut Indonesia 3: 13-21.

Awasthi A, Rathore G, Sood N, Khan MY, Lakra WS. 2013. Establishment of a leukocyte cell line derived from peritonial macrophages of fish, Labeo rohita (Hamilton, 1822). Cytotechnology 67: 85-96.

Bernfeld P. 1955. Amylases $\alpha$ and $\beta$. Method Enzymol 1: 149-158.

Bunnoy A, Na-Nakorn U, Srisapoome P. 2019. Probiotic effects of a novel strain, Acinetobacter KU011TH, on the growth performance, immune responses, and resistance against Aeromonas hydrophila of bighead catfish (Clarias macrocephalus Günther, 1864). Microorganism 7: 613-643.

Chen SC, Yoshida T, Adams A, Thompson KD, Richards RH. 1996. Immune response of rainbow trout to extracellular products of Mycobacterium sp. Journal of Aquatic Animal Health 8: 216-222.

Chen SW, Liu CH, Hu SY. 2018. Dietary administration of probiotic Paenibacillus ehimensis NPUST1 with bacteriocin-like activity improves growth performance and immunity against Aeromonas hydrophila and Streptococcus iniae in Nile tilapia Oreochromis niloticus. Fish \& Shellfish Immunology 84: 695-703.

Chen H, Yuan G, Su J, Liu X. 2019. Hematological analysis of Ctenopharyngodon idella, Megalobrama amblycephala and Pelteobagrus fulvidraco: Morphology, ultrastructure, cytochemistry and quantification of peripheral blood cells. Fish \& Shellfish Immunology 90: 376-384. 
Dimitroglou A, Merrifield DL, Carnevali O, Picchietti S, Avella M, Daniels C, Gúroy D, Davies SJ. 2011. Microbial manipulations to improve fish health and production - a Mediterranean perspective. Fish \& Shellfish Immunology 30: 1-16.

Djauhari R, Widanarni, Sukenda, Suprayudi MA, Zairin-Jr M. 2016. Characterization of Bacillus sp. NP5 and its application as probiotic for common carp Cyprinus carpio. Research Journal of Microbiology 11: 101-111.

Ferguson RMW, Merrifield DL, Harper GM, Rawling MD, Mustafa S, Picchietti S, Balcazar JL, Davies SJ. 2010. The effect of Pediococcus acidilactici on the gut microbiota and immune status of on-growing red tilapia Oreochromis niloticus. Journal of Applied Microbiology 109: 851-862.

Flores ML. 2011. The use of probiotic in aquaculture: an overview. International Research Journal of Microbiology 2: 471-478.

Fyzul AN, Harbi AHA, Austin B. 2014. Review: developments in the use of probiotics for disease control in aquaculture. Aquaculture 431: 1-11.

Gong L, He H, Dongjie L, Cao L, Khan TA, Yanping L, Lifei P, Liang Y, Xuezhi D, Yunjun $\mathrm{S}$, Youming Z, Ganfeng Y, Shengbiao H, Liqiu X. 2019. A new isolate of Pediococcus pentosaceus (SL001) with antibacterial activity againts fish pathogens and potency in facilitating the immunity and growth performance of grass carps. Frontiers in Microbiology 10: 1-14

Hamtini, Widanarni, Meryandini A. 2015. Isolation and selection of Bacilus sp. from catfish Clarias sp. as a potential probiotic. Jurnal Biologi Indonesia 11: 11-19.

Hanif A, Bakopoulos V, Dimitriadis GJ. 2004. Maternal transfer of humoral specific and non-specific immune parameters to sea bream Sparus aurata larvae. Fish \& Shellfish Immunology 17: 411-435.

Hauville MR, Zambonino-Infante JL, Bell JG, Migaud H, Main KL. 2016. Effects of a mix of Bacillus sp. as a potential probiotic for florida pompano, common snook and red drum larvae performances and digestive enzyme activities. Aquaculture Nutrition 22: 51-60

KKP [Pusat Data Statistik dan Informasi Kementerian Kelautan dan Perikanan]. 2017. Produksi dan Nilai Produksi Budidaya Lele Menurut Provinsi 2003-2016.
Michael ET, Amos SO, Hussaini LT. 2014. A review on probiotics application in aquaculture. Fisheries and Aquaculture Journal 5: 111-113.

Nasrullah H, Nababan YI, Yanti DH, Hardiantho D, Nuryati S, Junior MZ, Ekasari J, Alimuddin. 2019. Identifikasi dan analisis ekspresi gen lisozim tipe-C dan tipe-G pada ikan lele dumbo setelah infeksi Aeromonas hydrophila. Jurnal Akuakultur Indonesia 18: 1-10.

Nayak SK. 2010. Review probiotics and immunity: a fish perspective. Fish \& Shellfish Immunology 29: 2-14.

Neissi A, Rafiee G, Nematollahi M, Safari O. 2013. The effect of Pediococcus acidilactici bacteria used as probiotic supplement on the growth and non-spesific immune responses of green terror Aequidens rivulatus. Fish \& Shellfish Immunology 35: 1976-1980

Putra AN, Widanarni. 2015. Screening of amylolytic bacteria as candidate of probiotic in tilapia Oreochromis sp.. Research Journal of Microbiology 10: 1-13.

Rosyidah E, Meryandini A, Sunarti TC. 2013. The use of lactic acid bacteria and cellulolytic bacteria to improve the chemical properties of corn flour. Makara Journal of Science 17: $75-80$.

Silarudee S, Tongpim S, Charoensri N, Doolgindachbaporn S. 2019. Effect of a probiotic Lactobacillus plantarum CR1T5 dietary supplements on non-specific immunity in black eared catfish (Pangasius larnaudii). Journal of Pure and Applied Microbiology 13: 289-296

Sugiani D, Sukenda, Harris E, Lusiastuti AM. 2013. Vaksinasi ikan tilapia Oreochromis niloticus menggunakan vaksin monovalen dan bivalen untuk pencegahan penyakit motile aeromonas septicemia dan streptococcosis. Jurnal Riset Akuakultur 8: 229-239.

Tamamdusturi R, Widanarni, Yuhana M. 2016. Administration of microencapsulated probiotic Bacillus sp. NP5 and prebiotic Mannan Oligosaccharide for prevention of Aeromonas hydrophila infection on Pangasianodon hypophthalmus. Journal of Fisheries and Aquatic Science 11: 67-76.

Turnip ER, Widanarni, Meryandini A. 2018. Seleksi bakteri asam laktat sebagai probiotik dan evaluasi kinerjanya pada ikan lele gnotobiotik Clarias sp. Jurnal Akuakultur Indonesia 17: 68-80. 
Uribe C, Folch H, Enriquez R, Moran G. 2011. Innate and adaptive immunity in teleost fish: a review. Veterinarni Medicina 56: 486-503.

Valipour AR, Shahraki NH, Biria HA. 2018. Effect of probiotic Pediococcus acidilactici on growth and survival of kutum Rutilus kutum fingerlings. Iranian Journal of Fisheries Sciences 17: 35-46

Van Doan H, Hoseinifar SH, Khanongnuch C, Kanpiengjai A, Unban K, Van Kim V, Srichaiyo S. 2018. Host-associated probiotics boosted mucosal and serum immunity, disease resistance and growth performance of Nile tilapia Oreochromis niloticus. Aquaculture 491: 94-100.

Walter HE. 1984. Method with hemoglobin, casein and azocoll as substrate. Di dalam: Bergmeyer HU, editor. Methods of Enzymatic Analysis. Ed ke-3. Weinhem (JE): Verlag Cheime. hlm 270-277

Widanarni, Nopitawati T, Jusadi D. 2015. Screening of probiotic bacteria candidates from gastrointestinal tract of Pacific white shrimp Litopenaeus vannamei and their effects on the growth performances. Research Journal of Microbiology 10: 145-157. 